\title{
Chapter Ten: Economic Globalization and Strategic Peacebuilding
}

\section{Jackie Smith}

PUBLISHED: 2009 “Globalization and Strategic Peacebuilding” Pp. 247-269 in Daniel Philpott and Gerard Powers, editors. Strategies of Peace. New York: Oxford University Press.

In numerous countries where peace agreements have held without a relapse into conflict beyond the critical period, the structural factors lying at the source of the original conflict remain unaddressed and continue to fester. From Cambodia and Guatemala to East Timor, serious issues related to land tenure, property rights, rule of law, political participation and transitional justice continue to pose serious challenges to peace consolidation and peacebuilding. ${ }^{1}$

The post-Cold War era has been marked by a proliferation of persistent intra-state conflicts, many of which have frustrated international attempts to promote peaceful conflict resolution and the emergence of more peaceful societies. By many measures, international peacebuilding operations have achieved only mixed success or have simply failed, and nearly half of all "post-conflict" countries see a return of violent struggle. ${ }^{2}$ This chapter argues that an important reason for the failure of multilateral peacebuilding interventions is that these initiatives incorporate a set of assumptions about the benefits of market liberalization that are inaccurate. More effective intervention to end violent conflicts requires efforts to better understand how economic globalization impacts the dynamics of civil wars. Contemporary violent conflicts are not purely localized phenomena but rather they are deeply embedded within a global context of complex political and economic relationships. Strategic peacebuilding cannot occur without greater attention to these relationships and how they reproduce power and inequality in the global political and economic systems.

Recent studies on the impacts of multilateral peacebuilding initiatives have concluded that these interventions have, on the whole, not been terribly successful at helping societies transition from states of civil war to long-term, sustainable peace. ${ }^{3}$ Two important recent studies of peacebuilding operations - those by Collier et al. ${ }^{4}$ and Paris $^{5}$-- conclude that future 
interventions must subordinate market-liberalization policies to those that strengthen the capacities of institutions to manage societal conflicts. Paris, for instance, calls his proposed strategy "institutionalization before liberalization." But I would argue that these studies don't go far enough in their prescriptions because they cling to two important assumptions. First, they treat market liberalization and political liberalization, or "market democracy," as inherently linked and complementary processes, both of which are seen as essential to peacebuilding work. Second, they see economic liberalization as a central element of peacebuilding, even while they argue for its more gradual introduction in post-conflict settings. While there may indeed be relationships between economic liberalization and the conditions that foster peace, and while open markets might be associated with more open political systems, there is considerable debate among social scientists about the nature of these relationships. Market liberalization can proceed in highly authoritarian contexts, and highly democratic countries may in fact limit their participation in global markets in response to democratic pressures. Moreover, existing analyses show that economic liberalization can in fact undermine efforts to rebuild social institutions and foster political liberalization in war-torn societies. ${ }^{6}$ This chapter interrogates some key assumptions behind contemporary peacebuilding operations and the proposals to strengthen them, exploring whether or not the conventional wisdom about the relationship of market liberalization to peacebuilding processes is consistent with existing evidence.

What becomes apparent in this analysis is that much research in the area of peacebuilding fails to address adequately questions of power and its distribution. ${ }^{7}$ Sidelining power questions can often serve on a practical level to expedite cease-fire agreements and on an analytical level to generate more parsimonious models of conflict dynamics. But asymmetries of power can mask structural sources of conflicts that can resurface over time. Therefore, by failing to address 
power imbalances, conflict analysts and practitioners seeking to reduce violent conflict will fail to identify effective peacebuilding strategies. "Strategic peacebuilding" should imply, therefore, a central focus on questions of how power is distributed among conflicting parties along with intervention strategies that seek to reduce the inequities in power that can lead to violent conflict.

Globalization has meant an increasing concentration of political and economic power at the global level. ${ }^{8}$ Because of this, strategic peacebuilding should also adopt a perspective that embeds the local within a broader social and political context. As global integration expands along numerous dimensions, it becomes even more important that conflict analysts adopt a global systemic framework. Contemporary states are embedded within complex sets of economic and political relationships, as are an array of other transnational actors such as transnational corporations and civil society groups. Conflicts within states are often reflections of these broader sets of ties, and indeed these apparently localized conflicts depend upon resource flows that extend well beyond national borders. ${ }^{9}$ Andrew Hurrell describes a "triple anchorage of states" in the international system of states, in the global capitalist economy, and in transnational civil society. ${ }^{10}$ These webs of interdependence shape conflicts within as well as between states, and effective interventions to end violent conflicts must account for these relationships between local and global contexts.

Peacebuilding missions have been described as "transmission mechanisms" of neoliberal models of the state. ${ }^{11}$ Paris argues that, far from being technical and neutral exercises in conflict management, multilateral peacebuilding operations advance liberal market democracy as the preferred model for domestic governance, advancing a "world revolution of Western liberalism." ${ }^{12}$ They do so by: 1) encouraging parties to include political and economic liberalization measures into peace agreements; 2) providing technical assistance in constitution- 
writing and other governance tasks; 3) imposing political and economic conditionalities on parties in exchange for financial and other assistance; and 4) by performing governance functions in transitional or failed state contexts. ${ }^{13}$

Significantly, this transfer of governance templates is from the rich, northern, core of the global economy to the comparatively poor, southern, and post-colonial periphery. In short, peacebuilding itself reflects a long history of inequality in the world system, and it incorporates various forms of power -including structural, institutional, and symbolic power-that remains largely unexamined in existing literature. Robinson demonstrates, for instance, how peacekeeping operations in Nicaragua and Haiti were used to reorganize government practices to make them conform to the needs of globalizing capitalist interests. ${ }^{14}$ Thus, peacekeeping can be seen as one mechanism for the development of what Robinson calls the "neoliberal state," or the transformation of national states into entities that support the trade liberalization agenda of globalized capital. ${ }^{15}$ In this sense, peacekeeping operations are a part of the "revolution from above," that helped expand the global economy in recent decades. ${ }^{16}$ Strategic peacebuilding approaches, therefore, require a critical analysis of how power is reflected and reproduced in the operation of peace intervention missions. They also demand greater attention to the assumptions behind these missions and their objectives.

A critical look at peacekeeping and peacebuilding operations suggests that they are designed largely to protect if not to promote the interests of the northern, core states that enjoy privileged influence in global institutional contexts. Peacebuilding interventions-like other international initiatives such as global trade agreements and multilateral development lending-have helped to reproduce neoliberal economic policies. Unlike global trade and financial institutions, however, peacebuilding missions advocate economic liberalization not as an end in 
itself, but rather as a (presumed) means of promoting economic growth that will reduce violent conflict. However, relatively little empirical research has been done to critically examine this assumption that economic liberalization will actually contribute to peacebuilding aims.

Also integral to the models of governance favored by market liberalization proponents are policies that reduce state regulatory capacities and expand incentives and opportunities for international investment. By reducing the capacities of states to define and defend public goods and by limiting the policy space available for democratic decision making, such practices may obstruct efforts to build stronger institutions and foster democracy in post-war states. Given these possible tensions between the practices of peacebuilding missions and the needs of societies emerging from violent conflicts, I examine four key assumptions in peacebuilding research and practice: First that market liberalization leads to economic growth; second that growth will solve the underlying problem of inequality that gives rise to conflicts; third that a neoliberal model of the state will be effective at promoting peace; and that multilateral peace and security can be improved without addressing fundamental inequities in the global economic order.

\section{Market Liberalization and Growth}

In their important World Bank-sponsored study of contemporary internal conflicts, Collier and his colleagues conclude that the "key root cause of conflict is the failure of economic development." ${ }^{17}$ Societies plagued with internal violence are very often those mired in poverty. Thus, a key strategy for breaking what Collier et al. call the "conflict trap" is to promote market liberalization, expanding the country's access to world markets as a means of promoting economic growth. But will market liberalization generate the growth needed to transform wartorn societies? 
Debates about the effects of trade liberalization and economic growth yield conflicting results, but the bulk of new work that is emerging suggests that initial optimism about trade liberalization's prospects were substantially over-stated. ${ }^{18}$ For instance, the World Bank recently reduced its projections of global gains from trade liberalization by nearly two-thirds, from $\$ 832$ billion to $\$ 287$ billion. And the projected benefits to the developing countries were reduced by more than $80 \%$ from $\$ 539$ billion to $\$ 90$ billion. ${ }^{19}$ The UNDP Human Development Report, moreover, states that " $[\mathrm{t}]$ he evidence to support the proposition that import liberalization is automatically good for growth is weak." ${ }^{20}$ The analysis of trade offered in the UNDP report suggests that, while trade liberalization might indeed be associated with growth in some countries at some times, there is no direct link between economic liberalization and growth. Other variables are important for explaining when liberalization helps generate growth and when it cannot. ${ }^{21}$ There is, in short, no automatic relationship between the two. Thus, despite two decades of radical economic liberalization policies and a doubling of world exports since the early 1990s, we still see a "persistent pool of non-developing low-income countries" that threatens world peace and stability. ${ }^{22}$

Another pattern that emerges from data on global trends in imports and exports suggests that the benefits of trade for poor countries are not at all comparable to the benefits experienced by rich countries. This should lead us to seriously question trade liberalization as an effective prescription for helping poor countries emerge from conflict traps. While developing countries are devoting substantially more of their national resources and energies to promoting exports, they have not achieved substantial gains in terms of global market shares. ${ }^{23}$ For instance, despite a growth in exports between 40-55\% African countries' share of world markets grew by just $0.3 \%$ in the $1990 \mathrm{~s}$. And India's share of world trade went up just $0.7 \%$ despite average annual 
growth of $10 \%$ during the $1990 \mathrm{~s} .{ }^{24}$ This type of economic growth will only contribute to evergrowing inequalities between countries as well as within them. ${ }^{25}$ If one considers the environmental and social costs associated with developing countries' increased participation in world markets, there is little overall benefit from trade in terms of expanding the resources available to most of the population in these regions.

More disturbing, however, is that the higher-income developing countries are finding that growth from trade is not readily sustained. Weisbrot ${ }^{26}$ and Bello ${ }^{27}$ found that economic growth rates in Latin America were markedly higher before the era of neoliberal reforms than they were after countries opened their borders. And many successful globalizers are finding their place in the highly stratified global production system slipping. Thus, countries like Mexico and Brazil are losing high value-added manufacturing jobs to Korea and China, and India's high tech sector is losing ground to lower-paying industries such as textiles and apparel. ${ }^{28}$ And globally, the terms of trade for developing countries have been declining over time: overall, declines for poor country terms of trade are $-.74 \%$; for India, the figure is $-1.62 \%$; and for Brazil, $-.18 \%{ }^{29}$ This record shows that economic policies designed to encourage foreign investment do not necessarily produce the economic growth expected by neoliberal policy analysts. While economic growththat is, expanding the resource pie for all residents of countries destroyed by war-is clearly vital to peace, there is sufficient evidence to warrant a search for strategies that don't rely on wealth trickling down to local communities from foreign investors and through export-based production and trade (see, Sambanis chapter, this volume). Since sustained peacebuilding work depends upon a stable and predictable social and economic environment, policies that link conflict-torn countries to a volatile and uncertain global economy are - as is becoming increasingly apparent-fraught with trouble. 
Critics of neoliberal policies often charge proponents of economic liberalization with engaging in what has been called "NAFTA math" - that is, reporting the economic gains from trade while neglecting to account for the associated costs, such as job losses, environmental destruction, and vulnerability to international markets. For instance, Public Citizen pointed out that the U.S. Trade Representative's reports on the job gains from NAFTA showed only those jobs created in export industries. The USTR forgot to subtract those jobs lost in industries that lost out to competition from new flows of imports. "NAFTA math" is rampant in many official accounts of trade's benefits, ${ }^{30}$ and those concerned with finding appropriate policy mechanisms to address the problems of violent conflict and fragile states should be careful to note these inflated assessments of trade benefits. In short, a "responsibility to protect" people in war-torn countries seems to require a far more vigorous search for better strategies to advance economic growth and more equitable distribution of wealth in war-torn countries.

Wise and Gallagher ${ }^{31}$ and Weisbrot et al..$^{32}$ note how trade proponents overlook important costs that liberalization imposes on poor countries. They examine the costs to developing countries of trade liberalization policies in terms of lost tax revenues from tariffs. They conclude that developing countries would lose more than $\$ 60$ billion in tariff revenue under the nonagricultural market access (NAMA) agreement within the World Trade Organization, around ten times the projected gains from trade liberalization. In countries where as much as $40 \%$ of government revenues come from tariffs, this cost is substantial, to say the least. It also will limit the capacities of poor governments to operate in the best of conditions, and thus we might rethink whether such policies are desirable for governments emerging from internal wars.

In sum, the evidence linking trade openness to economic growth are mixed, and there is no direct link between expanding a country's access to world markets and growing the economic 
pie that can help win over combatants and promote sustainable peace. Moreover, the experiences of the global north countries in the area of trade liberalization serve as poor predictors of the likely effects of trade on poor countries. The evidence shows consistently that the global south has enjoyed fewer and less consistent benefits from trade liberalization than their richer, early industrializing counterparts. Thus, Collier et al. are right to conclude that priority must be given to policies that promote peace over those that promote economic growth through markets. But we might ask whether the World Bank prescriptions are generating the kind of economic growth that can really lead to long-term peace. The mounting evidence that policies for economic liberalization are not generating the intended growth effects might help explain the past failures of peacebuilding operations.

Globalization's critics — whose ranks are gaining ever-larger numbers of policy elites-have developed elaborate analyses and feasible policy prescriptions aimed at remedying the shortfalls of neoliberal economic models. ${ }^{33}$ The essence of these approaches is a focus on production for local needs, local ownership and control, and attention to environmental and social contexts. These types of strategies can be part of an effort to quickly restore public services and to generate economic returns that are needed to encourage disarmament and conflict de-escalation. They have an advantage of helping increase the direct stakes all citizens would have in post-war peace agreements. So while growth and service restoration may take a bit longer, the process of engaging local communities and providing even limited resources to encourage local engagement and entrepreneurship helps build confidence and mobilizes local skills and energy in the peacebuilding process.

\section{Economic Liberalization and Inequality}


Collier and his colleagues found that the countries at greatest risk of civil war also experienced high levels of inequality. ${ }^{34}$ However, none of the study's numerous recommendations for improving peacebuilding work addresses this specific problem. Instead, there is an implicit assumption that the problem of inequality will be solved by policies that foster economic growth. This may be a valid assumption, but given that inequality is strongly linked to the escalation of conflicts, it bears greater scrutiny than the Collier study gives it. This section examines the question of whether and how economic liberalization affects patterns of inequality.

Economic orthodoxy links poverty reduction to economic growth. The conventional economic wisdom says that "a rising tide lifts all boats," that a growing economic pie will enrich all of society, that the benefits of growth will "trickle down" to generate other social benefits such as poverty reduction, environmental improvements, and the like. Thus, if economic liberalization generates growth, and growth helps reduce inequality, then economic liberalization is a good policy prescription for war-torn societies. But if economic liberalization does not generate more equitable distributions of wealth, and especially if it exacerbates inequality, then policy makers and analysts must seriously re-think its role in post-war contexts.

How has global economic liberalization impacted inequality in the world? While it is difficult to identify the specific causal variables, we have considerable evidence showing that economic globalization has had either no direct effect on inequality or that it may be contributing to rising inequality within and between countries. The UNDP recently reported that "for a majority of countries [economic] globalization is a story of divergence and marginalization." ${ }^{135}$ Global inequality has grown over recent decades of economic globalization, and now the richest $10 \%$ of the world population controls more than half the world's income, while the bottom $40 \%$ 
enjoy just $5 \%$ of world income. ${ }^{36}$ This inequality is even greater when measures of wealth are used in place of income. The UNDP data show that inequality in the global south is on the rise, and that this in turn, is slowing economic growth and curbing efforts at poverty reduction. The report argues - along with many social scientists and economists-- that inequality is a challenge to the international community, since it not only impedes market efficiency and economic growth, but it also undermines democracy and social cohesion - the very conditions that are required to reduce the likelihood that social conflicts will escalate into violent confrontations.

The 2005 Human Development Report paints a far gloomier picture of economic globalization than many previous official documents had. But the evidence is consistent with findings of scholars and other critics of trade liberalization as a policy panacea. Clearly the problem of persistent poverty and underdevelopment is less a function of scarce resourcesindeed the world is far richer by many material measures than it was in prior decades or centuries - than of the unequal distribution of those resources. ${ }^{37}$ In the previous section, I highlighted evidence showing that the benefits of trade were not equally distributed among the world's countries, and that the poorest countries and regions were gaining less than rich ones. This inequality in shares of world trade is reproduced in other measures of economic inequality. For instance, sociologists have found a consistent trend towards rising inequality within countries as well as between them. ${ }^{38,39}$ This growing gap between the rich and poor in the world, moreover, corresponds to the timing of neoliberal policy initiatives, which were first launched in the mid-1980s and disseminated through means such as international trade agreements and structural adjustment lending programs of the World Bank and IMF. The UNDP (2005) reports a current measure of world inequality, the Gini coefficient, of .67. ${ }^{40}$ This 
coefficient reflects a highly unequal global system with levels of inequality higher than those of the most unequal (and unstable) countries of the world. ${ }^{41}$

Although rising inequality is associated with the timing of global economic liberalization, we should not automatically assume a causal relationship, since a wide range of variables clearly affect global economic distributions. What can we say about whether and how economic globalization might be affecting inequality? The New Economics Foundation examined the extent to which the economic growth linked to neoliberal policies benefited the poorest segments of national populations. Their conclusions correspond with the UNDP report cited above, and they go further to argue that the 1980s and 1990s generated "anti-poor" growth: A very small and declining percentage of the world's economic growth went to those groups in greatest need. People living on less than $\$ 1 /$ day received just around $2 \%$ of the benefits from economic growth in the 1980 s, and this declined to less than $1 \%$ by 2000 . Those people living on $\$ 2 /$ day enjoyed about $5.5 \%$ of the growth in the early 1980 s but this share declined to just $3.1 \%$ by $2000^{42}$ Thus, just as the benefits of trade liberalization were reduced for poor countries, the benefits of economic growth are small and diminishing for poor people. The declines come as economic liberalization policies have expanded.

But does this association between economic globalization and rising inequality suggest a causal connection? We need theoretical work to show whether there is reason to think that economic liberalization is implicated in persistent and rising inequality. Sociologists identify labor market dynamics as an important part of this puzzle, and both empirical and theoretical work here shows that global economic integration has been systematically undermining the power of working people relative to the owners of capital. ${ }^{43} \mathrm{~A}$ major reason for this is that the policies pursued by the global financial institutions have pressed for the opening of national 
borders to flows of goods and services while allowing countries to close their borders to flows of people. This creates market distortions in the supply and demand of labor that artificially suppresses costs while also curtailing the possibilities for working people to benefit from expanding trade relationships. This has meant dramatic declines in rates of unionization around the world, and enhanced vulnerability of workers to job losses directly linked to import/export sectors. In the U.S., for instance, three-quarters of those workers losing their jobs due to traderelated competition re-entered the labor market at lower wages than they previously earned. ${ }^{44}$ And workers in the U.S. are comparatively powerful politically, so these losses are likely to be far greater in countries of the global south.

Weak labor rights mean more than simply a reduction in the benefits from economic liberalization that accrue to the poorest segments of the population. They also mean that a disproportionate share of the costs of liberalization is borne by the poorest people in society. ${ }^{45}$ Rather than helping to benefit the world's poorest people, the policies of economic liberalization tend to exacerbate the hardships faced by those most in need. Do the relatively poor, whose ranks may be growing due to rising global inequality, have a stake in a system that promotes expanded economic liberalization without specific efforts to remedy inequality? This is an important question for peacebuilding proponents to ask, since groups that are excluded from economic rewards can more readily be mobilized into violent opposition movements. Thus, Paris's analysis of post-conflict peace agreements concludes that more must be done to prioritize efforts to address the problem of inequality over the implementation of traditional market liberalization policies. ${ }^{46}$

Not only do inequality and the systematic reduction in the political power of working people undermine the prospects for stable peace agreements, but contemporary inequality also 
helps fuel wars. Collier and his colleagues argue that the ability of combatants in civil wars to field armies is enhanced under conditions of high unemployment. And both theory and empirical studies of the effects of economic liberalization show that unemployment is at least a temporary consequence, as losses in globally 'uncompetitive' industries are made up by new growth in exports. But experience to date suggests that the losses in employment outweigh employment gains in newly emerging sectors, at least in the short- and medium- terms. ${ }^{47}$ If societies at peace have trouble adapting their employment sectors to the needs of the global economy, then those plagued with internal conflict will have great difficulty developing policies to promote high employment when they must open their markets to compete with foreign imports. Thus, the employment disruptions caused by market liberalization may in themselves help prolong rather than curtail civil wars.

The persistence and especially the increases of inequality in the global system are serious threats to both localized peacebuilding efforts and to global peace. ${ }^{48}$ They are threats because they undermine the legitimacy and authority of existing institutions. As Hurrell argues, hierarchical modes of governance cost in terms of both legitimacy and efficiency (2005), and the conflicts we're seeing in the world since the end of the Cold War are likely reflections of this legitimacy crisis. More must be done to address this crisis and tackle the problem of inequality to provide the "political prerequisites for meaningful global moral community." 49

Thus, it would seem that policies aiming explicitly to enlarge the share of world and national income going to poor households would be far more effective at reducing poverty than are growth-oriented policies, which treat poverty-reduction as a by-product of growth. This would require that peacbuilding initiatives integrate distribution effects into their policy designs. ${ }^{50}$ This is obviously more difficult in the short-term, since it requires fundamental 
transformation of power relations, but it is essential for both the aim of economic development and for sustainable peacebuilding. As the UNDP concludes in regard to Guatemala:

No export growth strategy in Guatemala is likely to produce substantive benefits for human development without deep structural reforms to reduce inequalities and extend opportunity through the redistribution of land and other productive assets, increased public spending for the poor and targeted programmes aimed at breaking down the barriers facing indigenous people. Such measures will ultimately require a change in the distribution of political power in Guatemala. ${ }^{51}$

Ultimately, strategic peacebuilding must be about the redistribution of power (and resources) in society. Walton and Seddon concluded from their study of protests in global south countries against the austerity measures imposed by global financial institutions that these protests reflected a trend towards growing pressure for democratic reforms against the neoliberal,

"bourgeois" form of democracy [that is] more concerned with free trade than individual freedoms, more attentive to property than human rights, and downright skeptical about the social progress promised by earlier developmental states in contrast to the economic progress now promised by the market. ${ }^{52}$

In short, the persistent inequality in today's world means that large numbers of people lack a stake in the current system. The prevention of violence on the part of those denied the benefits of globalization will require either new efforts to include marginalized groups in social and economic life or even higher levels of coercion to repress dissent. There is little evidence that proposals to expand economic liberalization without explicit attempts to address the unequal distribution of resources and opportunities will generate lasting peace.

\section{Peace and the Neoliberal State}

Effective states are seen as crucial to sustaining peace agreements at the local level as

well as to maintaining regional and global peace and security. ${ }^{53}$ At the same time, peacebuilding prescriptions emphasizing economic liberalization may be undermining the ability of war-torn 
societies to re-establish capable and effective national states. Economic globalization has encouraged governments to adopt policies to promote international trade and investment. One way they have done this is through attaching conditionalities to international loans issued by the World Bank and IMF requiring policy changes favoring international investment and trade. Many of these policies are also integrated into post-war peacebuilding agreements as well, often as prerequisites for obtaining international assistance.

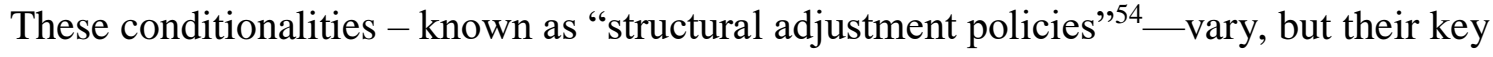
requirements include: reductions in public spending, privatization of public assets, government support for export industries, guarantees for international investors, and the elimination of domestic wage and price controls. ${ }^{55} \mathrm{By}$ "structurally adjusting" borrowing states, the policies effectively help transform national states into what Robinson calls "neoliberal states" whose domestic markets are more fully integrated into the global economy. ${ }^{56}$ In practice, what these policies do is reduce the capacities and governing role of the state while expanding the influence of international investors and global markets in the society. ${ }^{57}$ They also shift power away from representative institutions, workers, and consumers and towards international investors and export industries. $^{58}$

A growing body of research questions the effectiveness of structural adjustment policies for promoting economic growth and other benefits. ${ }^{59}$ Summarizing this research, Paris concludes that:

Twenty years after the advent of structural adjustment, the quarrel over [the influence of these programs on economic growth and levels of distributional inequality] remains largely unresolved; Neither the IMF nor the World Bank has been able to demonstrate convincingly that structural-adjustment programs promote economic growth, and the precise relationship between these programs and levels of poverty and distributional inequality is still hotly contested."60 
Even more importantly, the policies promoted by multilateral financial institutions may in fact be contributing to human rights violations, thereby protracting conflicts while also undermining possibilities for economic growth. Abouharb and Cingranelli, for instance, analyzed the effects of international financial policies on human rights practices, and they found that the structural adjustment policies advanced by the World Bank were associated with higher levels of violations of physical integrity rights, including freedoms from torture, political imprisonment, extrajudicial killing, and arbitrary disappearances. ${ }^{61}$

Despite this dubious record, structural adjustment policies continue to be integrated into international lending agreements and peace agreements, either through multilateral institutions or through bilateral pressures from the countries that are primary sources of official aid and private investment. ${ }^{62}$ These practices are counter-productive to peacebuilding work, since they limit the policy space available to governments that must prioritize the building or rebuilding of democratic institutions and the expansion of popular commitments to peace agreements. Rather than emphasizing these important goals, structural adjustment policies prioritize the expansion of foreign investment and market liberalization. The effects of these policies on democratic institution-building are seen as secondary to the aim of expanding market liberalization as a means of enhancing economic growth. But a critical look at these policies suggests that effective peacebuilding work may require a fundamentally different approach to structuring national institutions.

Kaldor and Luckham's analysis of post-Cold War conflicts identifies a generalized phenomenon that they argue is "almost the reverse of state and nation-building." ${ }^{63}$ They see the practices associated with economic globalization as contributing to the delegitimation of public authority that is fueling the escalation and proliferation of "new wars." They conclude that the 
only effective way to resist these new wars is to engage in systematic efforts to democratize politics and restore legitimate political authority. While Sambanis (this volume) calls for caution in this regard, the point that locals must have a stake in the economic choices that will define post-war development remains valid. International intervention can be designed to maintain a larger range of choice and control for the people in countries recovering from war, thereby creating incentives for locals to engage in peacebuilding processes. This prescription, however, is fundamentally different from that promoted by conventional peacebuilding interventions, which encourage the pursuit of economic growth as the main prerequisite to peace. Neoliberal states that are characterized by very limited policy space, by reduced capacity to regulate social actors, and by policy programs encouraging profit-seeking over other social aims are unlikely to build public authority and reverse this trend.

Typical peacebuilding prescriptions reduce the range of policy choices available in postconflict states, thereby obstructing efforts to build legitimate democratic institutions. Most states in the global south - whether or not they have experienced internal wars - have been forced to negotiate limits to their national sovereignty in return for international financing. ${ }^{64}$ Countries that borrow money from the World Bank or IMF and that undergo other international interventions such as internationally enforced peace agreements are not free to determine what economic programs they pursue. Rather than being subject to democratic mechanisms of deliberation and public accountability, major economic decisions are often left to elites or to technical experts acting outside of public scrutiny. ${ }^{65}$ While such policies may seem logical from the perspective of professional economists, they effectively depoliticize decisions that are at the heart of most societies - those affecting the fundamental organization of economic life and the distribution and use of societal resources. Thus, some of the most important decisions that 
govern any society are effectively withdrawn from the public sphere. This constraining of the effective policy space undermines the abilities of post-war societies to win the loyalties and confidence of citizens. This is true even where there are successful steps towards elections and other steps at democratization. For a democratic state that lacks authority and capacity to shape decisions that affect people's lives is an oxymoron.

In addition to limited space for economic policy deliberation, neoliberal states are also characterized by reduced capacities for regulating economic and other activities within their borders. Peter Evans refers to this model of the modern state as the "lean, mean state," since it emphasizes coercive capacities necessary for the protection of private property and promotion of social stability over social welfare. This reduction in state capacities comes at a time when we find an unprecedented concentration of wealth and power in the hands of private entities such as transnational corporations and transnational criminal networks. This latter development necessitates greater capacity for effective state governance on behalf of societal interests.

The studies of Collier et al. and Paris, however, show that effective attempts to end civil wars require strong domestic institutions that are capable of pursuing multifaceted policy programs. These states must win the loyalties of diverse and often conflicting social groups, and they must therefore be able to make parties feel they have real stakes in the strengthening and perpetuation of government institutions. At the same time, they must be able to regulate private actors that can disrupt peace or otherwise contribute to the exclusion of social groups. States whose primary purpose is seen to be the promotion of markets and profit-seeking activities are unlikely to be effective at limiting the business activities of groups perpetuating violent conflicts. And the reduction of state capacities for affecting the distribution of resources contributes to a concentration of resources in the hands of small numbers of people who remain beyond the 
control of weakened states. These weaknesses of states contribute to the dynamics of the conflict trap discussed by Collier et al. ${ }^{66}$ In short lean, mean, neoliberal states are unlikely to be able to effectively govern the practices of transnational actors, even when this is vital to the maintenance of peace. Nor are they likely to obtain legitimate authority necessary for reversing the trend seen by Kaldor and Luckham.

Another way that peacebuilding policies may constrain possibilities for states in post-war settings to escape from conflict traps is by privileging programs that emphasize profit-seeking over other social aims. The key assumption behind neoliberal policies is that markets free of government intervention allow actors to engage in the free pursuit of profit that is expected to enhance overall economic well being. But Collier et al. associate the pursuit of profit among groups engaged in civil wars with the perpetuation of these conflicts. ${ }^{67}$ While the conflicts themselves may not be grounded in explicit economic ambitions, as warring parties organize themselves to amass the resources needed to wage protracted conflict, they tend to become increasingly committed to profit-seeking activities during the course of armed struggles. And these profit-seeking practices themselves often depend upon the maintenance of armed conflict or at least the absence of effective governance institutions. Thus, the dynamics of wars interact with the incentive structures encouraged by neoliberal economic policies to reinforce conflict traps.

In sum, most analysts of conflict argue that effective peacebuilding work involves the construction of institutions that enjoy widespread legitimacy. Such institutions must be democratic and effective at implementing popular preferences and curbing abuses of power. But the privileging of neoliberal models of the modern state undermines both the legitimacy and political effectiveness of states. This is particularly problematic in societies emerging from 
armed conflict, where post-war institutions must expand the stakes of all actors in the new government and where high levels of inequality often require strong state capacities for economic regulation and redistribution.

\section{Peacebuilding and Global Governance}

A final assumption inherent in predominant models of post-conflict peacebuilding is that multilateral peace and security can be improved without addressing fundamental inequities in the global economic order. While analysts have rightly identified the ways local and national armed struggles can threaten regional and global peace, the solutions offered typically fail to confront the ways that inequality in the global political order may be fueling more localized conflicts. Moreover, peacebuilding interventions that force warring parties to adopt market liberalization policies may be helping to perpetuate rather than reduce violent conflict.

Peace agreements encourage post-war states to become more integrated into a competitive global capitalist economy. But as Paris warns, "[c]apitalism...is inherently

competitive. It inevitably creates winners and losers, which can fuel social unrest." 68 Both Paris and Collier et al. argue for more cautious liberalization of post-war states, even as they maintain that integration into the global capitalist economy is an effective strategy for societies emerging from civil wars. But if capitalism itself "inevitably creates winners and losers" thereby fueling social unrest, is the promotion of globalized capitalism an effective strategy for promoting local or global peace and security?

While globalized capitalism has helped promote economic growth and new technological innovations, the ability of capitalist markets to maximize human well-being over the long-term has come under growing scrutiny. Indeed, the prescriptions of Paris and Collier et al. 
demonstrate that global markets are not sufficient for generating peace, and indeed I have argued that global markets can undermine the achievement of other conditions that are necessary for peace. Collier et al., for instance, argue that new systems of international governance are needed to manage international trade in natural resources so that warring parties cannot use illicit trade to finance wars. They also argue that poor states need global management of commodity prices to ensure the effective and stable governance of their countries. And they see a need for greater global social solidarity to enhance the flows of aid from rich to poor countries. Paris also emphasizes non-market policies aimed at fostering democratic cultures and empowering civil society. But the policy prescriptions in these studies place primary emphasis on making changes in the governance of countries marred by civil wars rather than in the international system itself.

A system-wide approach to addressing local and national conflicts, however, would lead us to question the extent to which the predominant, market-oriented approaches to peace agreements are likely to support long-term peace and security. Can the international community impose models of economic governance on societies emerging from violent conflict and expect them to build effective and inclusive democratic institutions? Can peaceful national and global societies exist within a global order that emphasizes economic competition and individual profit maximization?

These questions are vital, I think, to addressing the problem of violence in contemporary societies. But most conventional approaches to international peacebuilding and conflict intervention neglect them. If the global economic and political order is fueling conflicts at local and national levels, then national or local strategies will not, on their own, end the violence. Problems must be addressed at the level at which they originate, and thus strategic peacebuilders 
must ask the tough questions about how the global system is implicated in more localized struggles.

The UNDP Human Development Report argues that policies promoting social inclusion are necessary if we are to see a reduction in violence in contemporary societies. ${ }^{69}$ But as was stated earlier, the global capitalist system emphasizes economic competition, which necessarily excludes those without access to financial and material resources. Social exclusion is a major effect of the global neoliberal order. Thus, we must ask whether policies that enhance countries' participation in global capitalist markets should be as central a part of the solution to violent conflict as predominant discussions make them.

The privileging of globalized markets in the international policy discourse is also the result of highly unequal arrangements in the global political order. The ideologies guiding global neoliberalism and the dissemination of market liberalization policies emerged from the rich countries of the global north, and they were aided by the support of elites in the global south. But poor countries and people had little role in shaping this policy agenda, and the policies of the World Bank and IMF have served to erode the national sovereignty of borrowing states in favor of donor countries. ${ }^{70}$ Thus, the policy agenda of market liberalization is not one that emerges from a democratic foundation of deliberation among sovereign equals, but rather it reflects longstanding patterns of global domination and subordination. It is unlikely, then, that this policy approach can be a foundation for a stable and democratic peace.

The place of market liberalization in the international community's hierarchy of policy priorities also reflects major inequities in the global system that threaten long-term global peace and security. The international system is rife with contradictory policies and practices, and one of the most glaring is the tension between the international financial institutions and the United 
Nations Charter. The UN was designed to prevent wars and promote conditions that are conducive to international peace. The World Bank, IMF, and World Trade Organization, in contrast are part of the Bretton Woods system that aimed to expand global trade and international investment. While the Bretton Woods system was initially to fall within the jurisdiction of the United Nations system, in practice the global financial institutions operate independently of the UN. Their policies, moreover, are increasingly seen as being at odds with UN principles of equity, human rights, and environmental sustainability. ${ }^{71}$

Over recent decades, the United States government and other key proponents of globalized capitalism have worked to systematically reduce the role of the United Nations in global affairs while making the global financial institutions more influential. ${ }^{72}$ The major effect of this policy has been to advance neoliberal agendas through largely coercive measures while subordinating other policy objectives to that of expanding global markets. As a result, a comparison of global policy arenas reveals major contradictions among policy aims, outcomes, and norms. For instance, market-oriented policies encourage economic growth, expanding consumption, and participation based on financial means. In contrast, environmental preservation policies emphasize the limits of the natural environment and the precautionary principle. And human rights policies emphasize equality, human needs, and universal rights of participation based on shared humanity. The subordination of the UN to the global financial institutions has meant a prioritization of markets over sustainability and human rights. These institutional contradictions complicate efforts to promote sustainable peace at local or global levels.

Not only do institutional arrangements make it difficult to guarantee that policies promoting equity and sustainability gain at least equal footing with those promoting economic 
growth, but they also are likely to complicate efforts to build democratic cultures that are conducive to peace. An international system that prioritizes markets and economic growth places the aim of profit-seeking over other social objectives contributes to social exclusion and complicates governance at all levels. Thus, policies that seek to restrain economic competition in favor of political or environmental security face important political hurdles. Global neoliberalism has fostered an ideology of competition and "market fundamentalism" thatdespite losing some of its luster in recent years—-work against efforts to foster democratic civil society and to promote a global culture of solidarity and human rights. ${ }^{73}$

In sum, creating a global economic context that prevents combatants from exploiting natural resources to finance civil wars, that provides poor country governments with predictable and stable sources of income, and that reduces rather than exacerbates inequalities of wealth and income requires fundamentally different approaches to peacebuilding from those emphasized in most mainstream policy discourse. To reverse the escalation of internal conflicts and to foster stable and long-term peace, the international community must confront fundamental inequalities in the global system itself that are contributing to conflicts at local, national, and regional levels.

\section{Conclusion}

Strategic peacebuilding requires an analytical framework that considers how local actors are embedded within broader economic and political relationships that extend beyond the national to regional and global levels. While much intervention must take place at the level where violent conflict is experienced most directly, the analyses of the causes of civil wars and their perpetuation show that work must be done beyond local and national levels to address the causes of violence. A global system that privileges markets and opposes state intervention in 
economies also provides fertile ground for illicit trade that can help finance civil wars. Policies that contribute to rising inequalities at global and national levels fuel grievances that can be used to mobilize groups against one another. And an undemocratic global political order is unlikely to foster the values and cultural practices that will support democracy at other levels.

Major studies of international interventions in civil wars have concluded that market liberalization policies can undermine peace strategies. Nevertheless, these studies continue to support the overall policy of market liberalization. I would argue that we need to de-link the peacebuilding agenda from the neoliberal "globalization project," which emphasizes economic growth and the globalization of markets at the expense of other policy objectives. ${ }^{74}$ While economic growth can expand resources available for peacebuilding, it is more important for policymakers in post-conflict settings to actively work to reduce inequality through redistributive policies. And while market liberalization might encourage economic growth, the privileging of global over local and national markets may not serve the development needs of most post-war societies. States require greater policy making autonomy and capacity for action than they are typically allowed in most peace agreements, trade agreements, and international financial agreements. ${ }^{75}$ There must be greater coordination and coherence in international policy prescriptions across different governance sectors to strengthen state capacities.

The 1980s and 1990s have seen a very rapid expansion of the global economic order, and the global political system needs to catch up if we are to have a global economy that serves the needs of people rather than corporations. ${ }^{76}$ Although there is widespread rhetorical support for the idea of democracy, we lack global institutions that can effectively protect democracy at local and national levels. As governments bring more policy concerns to inter-governmental bodies like the United Nations and World Trade Organization, they effectively reduce democracy at the 
national level. ${ }^{77}$ Following the work of Karl Polanyi (1944), we might argue that we need to embed the global economy within a global society that is guided by principles of equity, human rights, and environmental sustainability. ${ }^{78}$ Such a society will require major changes to global institutions to provide mechanisms for democratic participation and accountability comparable to those achieved in many national contexts. In short, democracy at the national level will be increasingly reduced without steps to democratize global political and economic institutions.

How might this be accomplished? One way is for peace intervention strategies to be more explicit in actively supporting a "democratic globalization network" that advances a more democratic global order. ${ }^{79}$ This democratic globalization network--which is largely centered on civil society actors, but also includes pro-democratic governments and international officials-must be empowered to more effectively counter the network of transnational corporations and political elites that have systematically advanced their preferred model of neoliberal globalization. Peace operations should serve to alter the relative balance of power between neoliberal and democratic agents. Currently they are reinforcing the already vastly superior resources of neoliberals at the expense of democrats. The policies and practices that enable democracy to flourish are not the same as--and in fact are contradicted by-policies that advance globalized capitalism. ${ }^{80}$

Thus, peacebuilders must prioritize policies that strengthen norms and practices conducive to democracy and human rights, rather than subordinating them to the needs of global markets. This would mean, for instance, that policies aiming to reduce poverty should focus directly on putting resources into the hands of poor people rather than on expanding economic growth in the hopes that some new wealth will "trickle down" to those most in need. It would also mean promoting policies that level the political playing field among citizens to promote 
more inclusive debates and policies. By taking steps to organizing global society around the values of cooperation and social solidarity rather than economic competition, the global community might help reduce new incidences of violent conflict while helping war-torn societies escape the conflict trap.

Scholars of peace initiatives have long argued for greater inclusion of civil society groups and women into peace processes. But these proposals have not been effectively incorporated into existing peacebuilding efforts. Below I summarize three major strategies that this analysis suggests might enhance the prospects for enhancing civil society's role in multilateral peacebuilding initiatives and the development of more effective and democratic strategies for the resolution of violent conflicts. ${ }^{81}$

First, leaders in movements and international institutions should support the development of more inclusive peacebuilding networks of non-state, governmental, and inter-governmental actors working to promote peace, democracy, and more equitable development. These should be self-conscious conscious alliances between international agencies and civil society actors committed to core democratic and multilateralist norms, working together to engage both states and private financial actors in the tasks of more democratic global governance. It is the relative imbalance of power between civil society and other actors that contributes to conflict escalation and persistent violence. Thus, activities of these multi-actor networks should aim specifically to reduce the inequalities of power between civil society actors, states, and the private sector and to promote democratic participation and accountability in governance.

Second, multi-actor peacebuilding networks should focus in the near-term on efforts to democratize global institutions. An overwhelming majority of UN member states favors a system that better reflects the interests of all its members. Civil society groups would also 
benefit from a UN system that is more representative of all the world's governments. And finally, these reforms would enhance the commitment to the UN System by countries and civil societies that have been largely disenfranchised from global policy making. These changes require focused efforts to bring together supportive governments and international officials and movement actors around a strategy for promoting UN and especially Security Council reforms, including, for instance, those recommended by the recent UN High Level Panel Report on Threats, Challenges and Change.

Third, peacebuilding networks must be more proactive in their efforts to empower actors who have been marginalized by existing political and economic structures. They must struggle to reign in the power of corporations in the global polity so that states and civil society actors can exert more control over decisions that affect their economic lives as well as their political choices. Serious efforts are also needed to enhance democratic accountability and participation within states. The recent report of the Panel of Eminent Persons on UN-Civil Society Relations has some good recommendations around which policy makers and activists can mobilize, such as the call for a new "Office of Constituency Engagement and Partnerships," with its own UnderSecretary General, a Civil Society Unit, and an Elected Representatives Liaison Unit. The World Social Forum process provides opportunities to make important connections among civil society actors in different parts of the world as well as between civil society and national and international officials. This process should be supported financially and engaged more seriously by national and international policy elites as a possible mechanism for advancing a more equitable, democratic, and just global political order. Such a global order is an essential prerequisite to peacebuilding everywhere. 


\section{$\underline{\text { Endnotes }}$}

${ }^{1}$ Necla Tschirgi, "Post-Conflict Peacebuilding Revisited: Achievements, Limitations, Challenges," in Prepared for the WSP International/IIPA Peacebuilding Forum Conference (New York, 2004), 10.

${ }^{2}$ Paul Collier and others, Breaking the Conflict Trap: Civil War and Development Policy (Washington, D.C.: The World Bank and Oxford University Press, 2003). See also Michael Doyle and Nicholas Sambanis, Making War and Building Peace: United Nations Peace Operations (Princeton, NJ: Princeton University Press, 2006); Stephen John Stedman, ed., Ending Civil Wars: The Implementation of Peace Agreements (Boulder, CO: Lynne Rienner Publishers, 2002).

${ }^{3}$ Roland Paris, At War's End: Building Peace after Civil Conflict (New York: Cambridge University Press, 2004); Tschirgi, "Post-Conflict Peacebuilding Revisited," Collier and others, Breaking the Conflict Trap.

${ }^{4}$ Collier and others, Breaking the Conflict Trap.

${ }^{5}$ Paris, At War's End.

${ }^{6}$ See, eg., Amy Chua, World on Fire: How Exporting Free Market Democracy Breeds Ethnic Hatred and Global Instability (New York: Anchor Books, 2003); John Markoff, "Transnational Democracy in Critical and Comparative Perspective: Democracy's Range Reconsidered," ed. B. W. Morrison (London: Ashgate, Forthcoming).

${ }^{7}$ See, eg., Michael Barnett and Raymond Duvall, "Power in Global Governance: Introduction" in eds. M. Barnett and R. Duvall, Power in Global Governance (New York: Cambridge University Press, 2005), 1-32.

${ }^{8}$ See, eg., Markoff, "Transnational Democracy in Critical and Comparative Perspective;" William Robinson, $A$ Theory of Global Capitalism (Baltimore, Md.: Johns Hopkins University Press, 2004); Philip McMichael, Development and Social Change: A Global Perspective, Third Edition (Thousand Oaks, CA: Pine Forge, 2003); John Markoff, "Globalization and the Future of Democracy," Journal of World-Systems Research 5 (1999): 242262. http://csf.colorado.edu/wsystems/jwsr.html.

${ }^{9}$ See, e.g., Neclâ Tschirgi, "Peacebuilding through Global Peace and Justice," Development 48 (2005): 50-56.

${ }^{10}$ Andrew Hurrell, "Power, Institutions and the Production of Inequality" in Power in Global Governance, eds. M. Barnett and R. Duvall (New York: Cambridge University Press, 2005), 33.

${ }^{11}$ Roland Paris, "International Peacebuilding and the 'Mission Civilisatrice'," Review of International Studies 28 (2002): 637-656.

${ }^{12}$ Ibid., 638.

${ }^{13}$ Ibid., 637-656.

${ }^{14}$ William Robinson, Promoting Polyarchy: Globalization, U.S. Intervention and Hegemony (Cambridge: Cambridge University Press, 1996).

${ }^{15}$ Neoliberalism refers to the idea-system favoring market liberalization and rules for a globalized economy. See Robinson, A Theory of Global Capitalism, 2004.

${ }^{16}$ Ibid.

${ }^{17}$ Collier and others, Breaking the Conflict Trap, 53.

${ }^{18}$ See, e.g., Kevin P. Gallagher. "The Demise of the Doha Round? Unpacking Developing Country Resistance" Forthcoming in Review of International Political Economy. 
${ }^{19}$ Timothy A. Wise and Kevin P. Gallagher, "Doha Round and Developing Countries: Will the Doha Deal Do More Harm than Good?” Research and Information System for Developing Countries, New Delhi, 2006.

${ }^{20}$ UNDP, Human Development Report 2005: International Cooperation at a Crossroads (New York: Oxford, 2005), 119.

${ }^{21}$ See, eg., review in Roberto Patricio Korzeniewicz and William C. Smith, "Protest and Collaboration: Transnational Civil Society Networks and the Politics of Summitry and Free Trade in the Americas," North-South Center, University of Miami, 2001.

${ }^{22}$ Collier and others, Breaking the Conflict Trap, 6.

${ }^{23}$ And indeed, this is why international trade negotiations and the Doha Development Round have stalled or collapsed.

${ }^{24}$ Human Development Report 2005, 117.

${ }^{25}$ Roberto Patricio Korzeniewicz and Timothy Patrick Moran, "World Inequality in the Twenty-First Century: Patterns and Tendencies" in ed. G. Ritzer, The Blackwell Companion to Globalization (Oxford: Blackwell Publishers, 2006).

${ }^{26}$ Mark Weisbrot, “Globalization on the Ropes," Harpers, May issue (2000): 6.

${ }^{27}$ Walden Bello, Dark Victory: The United States and Global Poverty (London: Pluto Press, 1999).

${ }^{28}$ Human Development Report 2005; Wise and Gallagher, "Doha Round and Developing Countries."

${ }^{29}$ Wise and Gallagher, "Doha Round and Developing Countries."

${ }^{30}$ See, eg., Ibid.; Mark Weisbrot and others, "Poor Numbers: The Impact of Trade Liberalization on World Poverty," Center for Economic Policy Research, Washington D.C., 2004. See also Robin Broad, "Research, Knowledge \& the Art of 'Paradigm Maintenance': The World Bank's Development Economics Vice-Presidency (DEC)," Review of international Political Economy 13 (2006): 387-419.

${ }^{31}$ Wise and Gallagher, "Doha Round and Developing Countries,” 2006.

${ }^{32}$ Weisbrot, et. al., "Poor Numbers," 2004.

${ }^{33}$ See, for instance, Cavanagh, John and Jerry Mander, Ed(s). Alternatives to Economic Globalization: A Better World is Possible, 2nd Edition. (Berrett-Koehler Publishers) 2004; "New Principles and Rules to Build an Economic System that Works for People and the Planet" Civil society statement to the G20 Summit, November 2008. At: http://www.choike.org/bw2/\#english2 (accessed 22 November 2008); Korten, David. The Great Turning: From Empire to Earth Community. (Barrett-Koehler) 2007. Stiglitz, Joseph. "Towards a New Paradigm of Development." pp. 77-107 in Making Globalization Good: The Moral Challenges of Global Capitalism, edited by J. H. Dunning. (Oxford University Press) 2003.

${ }^{34}$ Collier and others, Breaking the Conflict Trap, 4.

${ }^{35}$ Human Development Report 2005, 116.

${ }^{36}$ Human Development Report 2005, 4.

${ }^{37}$ Sen, Amartya. 1995. Inequality Reexamined. New York: Oxford University Press; Food and Agriculture Organization. 2006. The State of Food Insecurity in the World 2006: Eradicating world hunger - taking stock ten 
years after the World Food Summit. (Food and Agriculture Organization of the United Nations, Rome). At: http://www.fao.org/icatalog/inter-e.htm (Accessed 3 April 2007).

${ }^{38}$ There is some debate as to whether between country inequality is rising or stabilizing, and this emerges from the use of different economic measures. Studies using exchange rates find rising inequality, while those using purchasing power parity (PPP) find slowed or declining inequality at the world level. I agree with the contention by Korzeniewicz and Moran in Roberto Patricio Korzeniewicz and Timothy P. Moran, "Measuring World Income Inequalities," American Journal of Sociology 106 (2000): 209-214., that exchange rate studies are more reliable, given the measurement and aggregation errors associated with PPP.

${ }^{39}$ Salvatore J. Babones and Jonathan H. Turner, "Global Inequality," in Handbook of Social Problems, ed. G. Ritzer (Blackwell), 101-121; R. P. Korzeniewicz and Timothy P. Moran, "World EconomicTrends in the Distribution of Income, 1965-1992," American Journal of Sociology 102 (1997):1000-1039; Roberto Patricio Korzeniewicz and Timothy Patrick Moran, "World Inequality in the Twenty-First Century: Patterns and Tendencies," in The Blackwell Companion to Globalization, ed. G. Ritzer (Oxford: Blackwell Publishers, 2006).

${ }^{40}$ The gini coefficient is calculated by measuring the distribution of income across a population. A coefficient of 0 is a perfectly equal society where each proportion of the population controls a comparable proportion of the country's income (or wealth), a coefficient of 1 reflects a perfectly unequal society. The gini coefficient for one of the most equal societies, Sweden, is .25 and for one of the most unequal societies, Brazil, is .59. The United States gini coefficient is .45 .

${ }^{41}$ The gini coefficient for Namibia is .71; Lesotho, .63; Botswana, .63; Sierra Leone, .63; and the Central African Republic, .61. Compare with the U.S. at .40 and Denmark at .25 (UNDP Human Development Report 2005).

${ }^{42}$ New Economics Foundation, "Growth Isn't Working: The Unbalanced Distribution of Benefits and Costs from Economic Growth," New Economics Foundation, London, (2006): http://www.neweconomics.org/gen/uploads/ hrfu5w555mzd3f55m2vqwty502022006112929.pdf, Accessed 20 October 2006.

${ }^{43}$ Roberto Patricio Korzeniewicz and Timothy Patrick Moran, "World Inequality in the Twenty-First Century: Patterns and Tendencies," In The Blackwell Companion to Globalization, ed. G. Ritzer (Oxford: Blackwell Publishers, 2006); Sassen, Saskia. 1998. Globalization and its Discontents. (New York: The New Press).

${ }^{44}$ UNDP Human Development Report 2005, 124.

${ }^{45}$ See, eg., Bello, Dark Victory; UNDP Human Development Report 2005.

46 Roland Paris, At War's End: Building Peace after Civil Conflict, (New York: Cambridge University Press, 2004), 200-205.

${ }^{47}$ Wise and Gallagher, "Doha Round." The fact that more of the labor force today is comprised of internal or international migrants is also likely to affect the social dislocations that impact prospects for violent mobilizations, since people uprooted from home communities who later become unemployed may be particularly vulnerable to recruitment efforts by militant groups.

${ }^{48}$ Collier et al., Breaking the Conflict Trap.

${ }^{49}$ Hurrell, "Power, Institutions and the Production of Inequality" 55.

${ }^{50}$ See e.g., New Economics Foundation, “Growth Isn’t Working,” and Weisbrot et al., "Poor Numbers."

${ }^{51}$ UNDP Human Development Report 2005, 123. 
52 Walton, John and David Seddon. 1994. Free Markets and Food Riots: The Politics of Global Adjustment. (Cambridge, MA: Blackwell), p. 339.

${ }^{53}$ Chesterman, Simon, Michael Ignatieff, and Ramesh Thakur. 2005. "Making States Work: State Failure and the Crisis of Governance." (Tokyo: United Nations University Press); Collier et al., Breaking the Conflict Trap.

${ }^{54}$ In response to protests against the global financial institutions, officials have renamed structural adjustment policies to "Poverty Reduction Strategy Papers" or PRSPs. The content of the prescriptions in these agreements between borrowing governments and the global financial institutions, however, remains largely unchanged Bello, Walden. 2003. Deglobalization: New Ideas for Running the World Economy: Zed Books.. Also, the Bank and the Fund have failed to follow a requirement meant to prevent the problems associated with the earlier structural adjustment programs, namely that they include civil society groups in the development and implementation of PRSPs O'Brien, Robert. 2004. "The International Monetary Fund, The World Bank and Labour in Developing Countries.", Willetts, Peter. 2002. "Civil Society Networks in Global Governance: Remedying the World Trade Organisation's Deviance from Global Norms " in Colloquium on International Governance, Palais des Nations. Geneva.

${ }^{55}$ Robert O'Brien, "Workers and World Order: the Tentative Transformation of the International Union Movement," Review of International Studies (2000), 26:533-555., and Paris, At War's End., and William Robinson, A Theory of Global Capitalism, (Baltimore, Md.: Johns Hopkins University Press, 2004).

56 Robinson, A Theory of Global Capitalism.

${ }^{57}$ Nancy, Alexander, "Decentralization and Sovereignty: How Policy Space is Eroded," in Social Watch Report 2006: Impossible Architecture, edited by S. Watch, (Montevideo, Uruguay: Social Watch, 2006), 20-22.

${ }^{58}$ Robert O'Brien, “The International Monetary Fund, the World Bank and Labour in Developing Countries," Manuscript, McMaster University, Hamilton Ontario.

${ }^{59}$ Joseph Stiglitz, Globalization and its Discontents, (New York: W.W. Norton and Company, 2003); Weisbrot, "Poor Numbers."

${ }^{60}$ Paris, At War's End, 166.

${ }^{61}$ Rodwan M.Abouharb and David Cingranelli, "The Human Rights Effects of World Bank Structural Adjustment," International Studies Quarterly, (2006), 50: 233-262.

${ }^{62}$ Luke Eric Peterson, "Bilateral Investment Treaties and Development Policy-Making." (Winnipeg: International Institute for Sustainable Development \& Swiss Agency for Development and Cooperation, 2004).

${ }^{63}$ Mary Kaldor and Robin Luckham, "Global transformations and new conflicts," IDS Bulletin 32 (2001).

${ }^{64}$ Nancy Alexander, "Decentralization and Sovereignty: How Policy Space is Eroded," in Social Watch Report 2006: Impossible Architecture, ed. S. Watch (Montevideo, Uruguay: Social Watch, 2006), 20-22.

${ }^{65}$ See William D. Coleman and Tony Porter, "International Institutions, Globalization and Democracy: Assessing the Challenges," Global Society 14 (2000): 377 - 398; and Michael Goldman, Imperial Nature: The World Bank and Struggles for Social Justice in the Age of Globalization (New Haven: Yale University Press, 2005); and John Markoff and Veronica Montecinos, "The Ubiquitous Rise of Economists," Journal of Public Policy 13 (1993): 37 68; and Joseph Stiglitz, Globalization and its Discontents (W.W. Norton and Company, 2003).

${ }^{66}$ Collier and others, Breaking the Conflict Trap. 
${ }^{67}$ Ibid., 79.

${ }^{68}$ Paris, At War's End, 167.

${ }^{69}$ UNDP Human Development Report 2005, chapter 5.

70 Alexander, "Decentralization and Sovereignty;" Hurrell, "Power, Institutions and the Production of Inequality;" and Celine Tan, "Reclaiming Development: Streamline the Bretton Woods Institutions," in ed., S. Watch, Social Watch Reports 2006: Impossible Architecture (Montevideo, Uruguay: Social Watch, 2006), 23-25.

${ }^{71}$ Leslie Sklair, The Transnational Capitalist Class (Cambridge: Blackwell, 2001); Sigron Skogly, "Structural Adjustment and Development: Human Rights - An Agenda for Change?," Human Rights Quarterly 15 (1993): 751 ; and Tan, "Reclaiming Development."

${ }^{72}$ Smith, Jackie. 2008 Global Visions, Rival Networks: Social Movements for Global Democracy. (Baltimore: Johns Hopkins University Press).

73 Seyla Benhabib, “On the Alleged Conflict between Democracy and International Law," Ethics and International Affairs 19 (2005): 85-100; Leslie Sklair, Globalization and Its Alternatives (New York: Oxford, 2002).

${ }^{74}$ Philip McMichael, Development and Social Change: A Global Perspective $3^{\text {rd }}$ ed (Thousand Oaks, CA: Pine Forge, 2003).

${ }^{75}$ Kevin Gallagher, “The Demise of the Doha Round? Unpacking Developing Country Resistance.” Review of International Political Economy (Forthcoming).

76 Christopher Chase-Dunn, "Social Evolution and the Future of World Society," Journal of World Systems Research 11 (2006): 171-192.

77 See Markoff, Forthcoming 2004; and Charles Tilly, "Globalization Threatens Labor Rights," International Labor and Working Class History 47 (1995): 1-23.

${ }^{78}$ Korzeniewicz and Smith, 2001. "Protest and Collaboration."

${ }^{79}$ Smith, Global Visions, Rival Networks.

80 Tilly, 2005.

${ }^{81}$ For more detail see Jackie Smith, "Social Movements and Multilateralism: Moving from the 20th to $21^{\text {st }}$ Century" in Multilateralism Under Challenge? Power, International Order, and Structural Change, edited by E. Newman, S. Tharoor, and J. Tirman, 395-421, (Tokyo: United Nations University Press, 2006). 